\title{
Enhancing Chickpea Productivity through Cluster Frontline Demonstration
}

\author{
M. Sangeetha*, P.S. Shanmugam, P. Ayyadurai and M.A. Vennila \\ ICAR-Krishi Vigyan Kendra, Tamil Nadu Agricultural University, \\ Dharmapuri District, Tamil Nadu, India \\ *Corresponding author
}

Keywords

Demonstration, Integrated crop management, Grain yield, Technology gap, Chickpea

Article Info

Accepted:

25 April 2020

Available Online:

10 May 2020

\begin{abstract}
A B S T R A C T
Frontline demonstration on Chickpea was conducted at 25 farmers' holdings of Dharmapuri district during Rabi season of 2017-18 to demonstrate the integrated crop management technologies for getting higher yield and income by the farmers. The integrated crop management practices including improved variety $\mathrm{NBeG} 3$ were demonstrated under demonstration and it was compared with farmers practice. The results of the demonstration indicated that demonstration of integrated crop management practices along with improved variety recorded higher grain yield of $7.28 \mathrm{q} /$ ha and farmers practice recorded the lower yield of $6.07 \mathrm{q} / \mathrm{ha}$. The increase in grain yield of chickpea over farmers practice was 19.9 per cent. The extension gap of $1.21 \mathrm{q} / \mathrm{ha}$ recorded for grain yield between demonstration and farmers practice indicated that dissemination of integrated crop management practices including improved variety through demonstration is needed among the chickpea growers for achieving higher yield thereby income. Besides, demonstration of integrated crop management practices recorded higher net income of Rs.20265/ha with benefit cost ratio of 1.97 as against farmers practice wherein, the net income was Rs. 14122/ha with benefit cost ratio was 1.71 for every rupee investment.
\end{abstract}

\section{Introduction}

Chickpea (Cicer arietinum L.) is an important cool season pulse crop cultivated during rabi season under black soils. Its grain contains protein $(22 \%)$, carbohydrate $(63 \%)$, fat $(4.5 \%)$ and appreciable quantity of minerals such as calcium and iron (Miao et al., 2009). Being a legume crop, it improves soil fertility by fixing the atmospheric nitrogen upto 100 $\mathrm{kg} / \mathrm{ha}$ in the root nodules through the process of symbiotic nitrogen fixation (Schwenke $e t$ al., 1998). It serves as a good fodder and green manure crop (Namvar et al., 2011).In India it is cultivated in an area of about 106 lakh hectares with an annual production of 11.1 lakh tonnes and the productivity of 918 $\mathrm{kg} / \mathrm{ha}$ (Anonymous, 2016-17). It contributes $47 \%$ of the total pulse production and about $40 \%$ of total pulse growing area in the country. In Tamil Nadu it is cultivated in an area about 0.07 lakh hectares with the production of 0.04 lakh tonnes and with the average productivity of $649 \mathrm{~kg} / \mathrm{ha}$. 
In Dharmapuri district, farmers usually cultivate the chickpea in black soils under rainfed condition during rabi season. Farmers realizing the low yield of chickpea due to use of local or old variety, reuse of their own seeds, occurrence of moisture stress, poor management practices especially no use of fertilizers and pesticides for managing pod borer and fusarium wilt disease incidence. Mehra et al., (2018) reported that yield of chickpea is limited due to poor spread of improved varieties and production technologies, imbalanced nutrition, abrupt climatic changes and vulnerability to pests and diseases. Incidences of pod borer causes damage upto 30-40 per cent pods (Rahman, 1990) and root rot and wilt disease causes 10 to 25 per cent yield loss depending upon the stage of the crop (Mahendra, 1998). In this circumstance, frontline demonstration is an important extension tool through which the improved technologies along with high yielding variety can be disseminated among the farmers through seeing is believing concept. Hence, a frontline demonstration has been planned and conducted to address the constraints faced by the farmers in achieving the higher yield and income in chickpea cultivation.

\section{Materials and Methods}

To overcome the problems faced by the farmers and to create awareness among the farmers, frontline demonstration was taken up to demonstrate the potential of the drought tolerant, high yielding variety with the improved package of practices in comparison with farmers practice in the farmers' holdings of Dharmapuri district during Rabi 2017-18. Demonstration was conducted in 25 locations spread over in Palacode, Dharmapuri and Morappur blocks of Dharmapuri District. Prior to conducting demonstration the beneficiary farmers were educated and demonstrated on the various technological interventions to be followed in the demonstration. The soils of the experimental site were clay loam in texture, neutral to alkaline in soil reaction, non- saline, low to medium in available nitrogen, medium to high in available phosphorus and potassium status. Chickpea crop was sown during October $15^{\text {th }}$ to November $15^{\text {th }}, 2017$.

Each demonstration was conducted in 0.4 ha area, adjoining 0.4 ha area was selected for taking up farmers practice. The details on the technologies demonstrated in the frontline demonstration and farmers practice are given below.

Frontline demonstration with integrated crop management practices

Cultivation of new variety $\mathrm{NBeG} 3$

Spacing : 30 x $10 \mathrm{~cm}$

Seed treatment with biofertilizers viz., Rhizobium and Phospho bacteria each @ $25 \mathrm{~g} / \mathrm{kg}$

Seed treatment with Pseudomonas fluorescens @ 10g/kg seed and Trichoderma viride@ $9 \mathrm{~g} / \mathrm{kg}$ seed for the management of wilt disease

Nipping of terminal bud at 30 DAS

Soil drenching with Pseudomonas fluorescens @ $10 \mathrm{~g} / \mathrm{lit}$ at the time of wilt incidence

Integrated nutrient management :

Basal application of FYM @ 12.5t/ha

Recommended dose of NPKS @ 25:50:25:20 kg/ha

Soil application of TNAU pulses micronutrient mixture@7.5 kg/ha

Foliar spray of pulse wonder @ 5 kg/ha at peak flowering

Integrated pest management for pod borer

Integrated disease management for wilt disease 


\section{Farmers practice}

Cultivation of variety $\mathrm{CO} 4$

Spacing : $15-20 \times 10 \mathrm{~cm}$

Seed treatment practice : not followed

Nutrient management : not followed

Foliar nutrition : not practiced

IPDM practices : not followed

During sowing of crop, initial soil samples were collected from the experimental sites and analysed for their available nutrient status. Incidence of pod borer and fusarium wilt disease was observed during the crop growth stages. At the time of harvest, the growth and yield characters such as number of branches per plant, number of pods per plant, 100 seed weight (g) and grain yield $(\mathrm{q} / \mathrm{ha})$ were recorded both under demonstration and farmers practice. Economic analysis was done by calculating cost of cultivation, gross income, net income and benefit cost ratio.

\section{Results and Discussion}

Results on the effect of frontline demonstration and farmers practice on the growth and yield of chickpea are given in Table 1. Demonstration of Chickpea variety $\mathrm{NBeG} 3$ with integrated crop management practices has recorded higher number of branches per plant (14.3) and number of pods per plant (27.4). Farmers practice recorded lower number of branches per plant (9.33) and number of pods per plant (17.6). Besides, demonstration recorded higher 100 seed weight of $26.8 \mathrm{~g}$ and farmer practice recorded lower 100 seed weight of $25.6 \mathrm{~g}$. The higher seed weight observed under demonstration might be due to the good seed filling produced by the foliar spraying of pulse wonder during peak flowering stage which is rich in nutrients and plant growth regulator.

Adoption of integrated pest and disease management practices under demonstration recorded the lower incidence of pod borer $(4.6 \%)$, Fusarium wilt disease $(5.1 \%)$ incidence and farmers practice recorded lower incidence of 15.3 and $16.6 \%$, respectively. The lower pest and disease incidence under the demonstration might be due to the adoption of integrated pest and disease management strategies including seed treatment and soil drenching practices with bio control agents in chickpea.

Demonstration of Chickpea variety $\mathrm{NBeG} 3$ with integrated crop management practices recorded higher average grain yield of 7.28 $\mathrm{q} /$ ha (Figure 1). The farmers practice recorded lower average grain yield of $6.07 \mathrm{q} / \mathrm{ha}$. Adoption of improved variety along with integrated crop management practices increased the yield of Chickpea to the tune of 19.9 and 7.37 per cent compared to the farmers practice and state average yield, respectively. The increased yield under demonstration might be due to the combined effect of high yielding, drought tolerant variety and adoption of integrated crop management practices.

Similar results of increase in yield due to adoption of integrated crop management practices in Chickpea were reported by Kumar (2014) and Bhargav et al., (2017). The extension gap for grain yield i.e., the difference between the yield obtained from demonstration and farmers practice recorded was $1.21 \mathrm{q} / \mathrm{ha}$. It indicated that dissemination of integrated crop management practices including improved variety through frontline demonstration is needed among the chickpea growers for achieving higher yield and thereby income. 


\section{Economics}

The data on economics of chickpea reveled that gross cost was higher in demonstration with integrated crop management practices (Rs. 20722/ha) and lower in farmers practice (Rs. 19912/ha) (Table 2).

Table.1 Growth and yield parameters of chickpea under demonstration and farmers practice

\begin{tabular}{|l|c|c|c|c|c|}
\hline \multicolumn{1}{|c|}{ Particulars } & $\begin{array}{c}\text { Number of } \\
\text { branches } \\
\text { per plant }\end{array}$ & $\begin{array}{c}\text { Number } \\
\text { of pods } \\
\text { per } \\
\text { plant }\end{array}$ & $\begin{array}{c}\text { 100 seed } \\
\text { weight (g) }\end{array}$ & $\begin{array}{c}\text { Incidence } \\
\text { of pod } \\
\text { borer } \\
\text { (\%) }\end{array}$ & $\begin{array}{c}\text { Fusarium wilt } \\
\text { incidence (\%) }\end{array}$ \\
\hline Demonstration & 14.3 & 27.4 & 26.8 & 4.6 & 5.1 \\
\hline Farmers Practice & 9.33 & 17.6 & 25.6 & 15.3 & 16.6 \\
\hline
\end{tabular}

Table. 2 Cost benefits of demonstration and farmers practice in Chickpea

\begin{tabular}{|l|c|c|c|c|}
\hline \multicolumn{1}{|c|}{ Particulars } & $\begin{array}{c}\text { Gross cost } \\
\text { (Rs./ha) }\end{array}$ & $\begin{array}{c}\text { Gross income } \\
\text { (Rs./ha) }\end{array}$ & $\begin{array}{c}\text { Net income } \\
\text { (Rs./ha) }\end{array}$ & $\begin{array}{c}\text { Benefit Cost } \\
\text { Ratio }\end{array}$ \\
\hline Demonstration & 20722 & 40788 & 20065 & 1.97 \\
\hline Farmers Practice & 19912 & 34034 & 14122 & 1.71 \\
\hline
\end{tabular}

Figure.1 Grain yield (q/ha) of Chickpea under demonstration and farmers practice

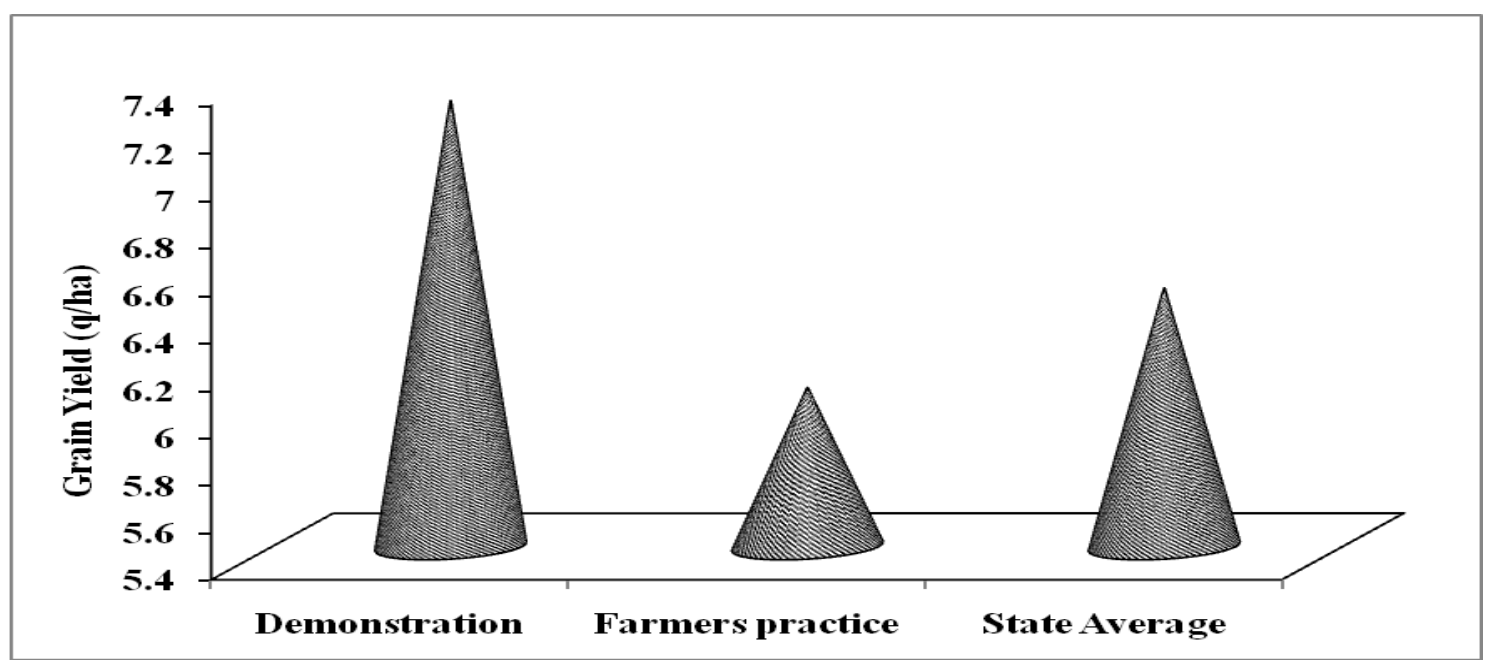

Farmers earned the net income of about Rs.20065/ha through the cultivation of Chickpea variety $\mathrm{NBeG} 3$ with integrated crop management practices and Rs.14122/ha with farmers practice. Hence, farmers realized the higher benefit cost ratio (1.97) under demonstration compared to farmers practice (1.71). The higher net income in the demonstration might be due to the higher grain yield recorded in demonstration of integrated crop management practices compared to farmers practice. Similar results of increase in net income through adoption of integrated crop management practices were reported by Meena (2017) in chickpea; Dhaka et al., (2010) in maize. 
The study concluded that, cultivation of Chickpea variety $\mathrm{NBeG} 3$ with integrated crop management practices substantially increased the yield and income of the farmers. The farmers are convinced with the technological interventions demonstrated under frontline demonstration programme and motivated the other farmers of the district to adopt the new variety with integrated crop management practices in cultivation of Chickpea for getting higher income.

\section{References}

Anonymous. 2016-17. Progress Report, Project Coordinators Report 2016-2017, AICRP on Chickpea, Kanpur.

Bhargav K.S., Khedkar N.S., GayatriVerma., Ambawatia, G.R., Nishith Gupta and Neerja Patel. 2017. Evaluation of front line demonstration on Chickpea in Shajapur District of MP. International Journal of Pure and Applied Biosciences, 5(4): 293-297.

Dhaka B.L., Meena B.S. and Suwalka R.L. 2010. Popularization of improved maize production technology through frontline demonstrations in south-eastern Rajasthan. Journal of Agricultural Science, 1(1): 39-42.

Kumar R. 2014. Assessment of technology gap and productivity gain through crop technology demonstration in chickpea. Indian Journal of Agricultural Research, 48(2):162-164.

Mahendra P. 1998. Diseases of pulse crops, their relative importance and management. Journal of Mycology and
Plant Pathology, 28(2): 114-122.

Meena M.L. 2017. Effect of front line demonstrations of chickpea cv. RSG-888 on farmers' field in rainfed condition of Rajasthan. India. Asian Journal of Agricultural Extension, Economics \& Sociology, 18(2): 1-7.

Mehra P., Singh A.P., Bhadouria J., Verma L., Panchal P. andGiri J. 2018. Phosphate homeostasis: Links with seed quality and stress tolerance in Chickpea. In: Pulses Improvement: Physiological, molecular and genetic perspectives, Edited by Wani, S.H. and Jain, M. pp.191-217.

Miao M., Zhang T. and Jiang B.2009. Characterisations of kabuli and desi chickpea starches cultivated in China. Food Chemistry, 113:1025-1032.

Namvar A., SeyedSharifi R., Sedghi M., AsghariZakaria R., Khandan T. and Eskandarpour, B.2011. Study on the effects of organic and inorganic nitrogen fertilizer on yield, yield components and nodulation state of chickpea (Cicer arietinumL.). Communications in Soil Science and Plant Analysis, 42(9): 1097-1109.

Rahman M.M. 1990. Infestation and yield loss in chickpea due to pod borer in Bangladesh. Bangladesh Journal Agriculture Research, 15(2):16-23.

Schwenke G.D., Peoples M.B., Turner G.L. and Herridge D.F.1998. Does nitrogen fixation of commercial, dryland chickpea and faba bean crops in north-west New South Wales maintain or enhance soil nitrogen?. Australian Journal of Experimental Agriculture, 38: 61-70.

\section{How to cite this article:}

Sangeetha, M., P.S. Shanmugam, P. Ayyadurai and Vennila, M.A. 2020. Enhancing Chickpea Productivity through Cluster Frontline Demonstration. Int.J.Curr.Microbiol.App.Sci. 9(05): 3517-3521. doi: https://doi.org/10.20546/ijcmas.2020.905.418 